\title{
An Ethnobotanical Study of Swamp Wetland Vegetation in Uasin Gishu County, Kenya
}

\author{
Josephine Mumbe Mulei, Donald F. Otieno, \\ and Augostino Osore Onkware
}

\section{Research}

\begin{abstract}
Ethnobotanical knowledge associated with wetland plants in Uasin Gishu County, Kenya, was assessed and documented. Data on the uses of plants, their local names, and parts used were collected through semi-structured interviews. Fifty wild plant species distributed across 45 genera and 23 families were cited as having traditional uses in the area. Of these, 26 were used as fodder, 14 as medicine, 12 as firewood, 9 as food, and 11 for construction. Some, like Cyperus papyrus L. and Acacia seyal Delile, had multiple uses. Thirty-one plants $(62 \%)$ of the total recorded were herbs, $13(26 \%)$ shrubs, $3(6 \%)$ trees, and 3 $(6 \%)$ climbers. Various plant parts were used for different purposes. Medicinal plants were useful in treating a total of 19 ailments and had various methods of preparation.
\end{abstract}

\section{Introduction}

Many years of people growing and using plants from the wild has resulted in the accumulation of indigenous knowledge on plants and their uses (Khan \& Khatoon 2007, Signorini et al. 2009). However, habitat loss, industrialization, migration of rural populations to urban areas, and cultural changes in indigenous communities are threatening this knowledge (Signorini et al. 2009, Zent 1999). Therefore, there is urgent need to document this knowledge before it vanishes.

Plant resources provide humans with materials that have economic, medicinal, and forage values (Bayafers 2000). This includes indigenous knowledge on the use and management of plant resources among the local people of an area (Bayafers 2000, Lulekal 2008, Signorini et al. 2009). However, when such resources are over-exploited and not used wisely, they can be eliminated from the environment, and the information associated with them may eventually be lost as well (Peters 1996). Ethnobotanical knowledge is useful for broadening our knowledge on plant use (Benz et al. 2000).

Uasin Gishu County, Kenya, has many swamp wetlands which benefit the local people (e.g., harvesting of plants for food, medicine, and firewood). They also act as grazing grounds, especially during the dry season (Odongo 1996). Currently, human impact on the wetlands is pronounced, potentially resulting in loss of plants and knowledge of people living around the wetlands. The goal of this study was to compile a checklist of ethnobotanical knowledge of wetland plant use from people living around the swamps in Uasin Gishu County.

\section{Methods}

\section{Study area}

Uasin Gishu County is located in mid-western Kenya, Rift Valley Province, between $34^{\circ} 55^{\prime} 33^{\prime \prime}$ and $36^{\circ} 38^{\prime} 58^{\prime \prime} E$ and

\footnotetext{
Correspondence

Josephine Mumbe Mulei, Donald F. Otieno \& Augostino Osore Onkware, Department of Biological Sciences, School of Science, University of Eldoret, P.O. Box 112530100, Eldoret, KENYA.

josephinemumbe@gmail.com,

dfotieno@yahoo.co.uk,

aonkware@yahoo.com
}

Ethnobotany Research \& Applications 12:315-324 (2014)

Published: 15 July 2014 
between $0^{\circ} 2$ '44"S and $0^{\circ} 55^{\prime} 56$ "N (Figure 1; after Njuguna 1996, Odongo 1996). The total land area of the county is approximately $3218 \mathrm{~km}^{2}$ (GoK 2002) with large- and small-scale farming of maize and wheat being the main activities for which the land is used. The county has a total population of approximately 829,046 people (Kahuthu et and $1500 \mathrm{~mm}$, with two peaks in May and August and a drier spell from November to February (GoK 2002). The mean annual temperature is $23^{\circ} \mathrm{C}$. Four swamps-Marula, Leseru, Singilai, and Chepkongony-were selected for lic swamps located about $9 \mathrm{~km} \mathrm{NE}, 15 \mathrm{~km} \mathrm{NW}, 40 \mathrm{~km} \mathrm{SE}$, and $27 \mathrm{~km} \mathrm{NE}$ of Eldoret town, respectively. Combined they cover a total area of about $11.8 \mathrm{~km}^{2}$. The catchment area of the swamps is under large-scale wheat and maize cultivation. The main human activities within the swamps include farming of various vegetables like Solanum nigrum L. and Brassica oleracea var. acephala DC. and harvesting of wetland plants. The swamps are a source of domestic water supply as well as cattle watering and grazing points, especially during the dry season. al. 2005). The mean annual rainfall ranges between 1100 the study (Figure 1). They are all permanent riverine pub-

\section{Methods}

Ethnobotanical data was collected using semi-structured interviews held from 2006 to 2007 . The interviews were conducted using a previously developed questionnaire. Information was collected on the uses of wild plants from people living in homes neighboring the swamps. The homes were selected randomly. The interviews were individual, and the informants were selected independent of their age or gender. The interviewers were comprised of both men and women. A total of 80 volunteers of different age groups, 20 per swamp, were interviewed. A majority of them were local people without any scientific knowledge who were born or had spent most of their lives in the area. No appointment was made prior to the visits. The interviews were done in the field in order to minimize the risk of confusing identity of plant species. Kiswahili, Nan$\mathrm{di}$, and Keiyo languages were used during the interviews. The interviews focused on basic questions concerning the informants' knowledge of the uses of local plants, including their local names and the parts used. For medicinal plants, the methods of preparation and ailments treated were also recorded.

Plants were collected with the interviewees in situ and identified using taxonomic keys in Agnew and Agnew (1994), Beentje (1994), Ibrahim and Kabuye (1987), Haines and Lye (1983), Clayton (1970, 1974, 1982), and by comparing them with already identified herbarium specimens at the East African Herbarium in Nairobi. Later they were grouped into their various use-categories. Voucher specimens of the collected plants were dried, pressed, and de-
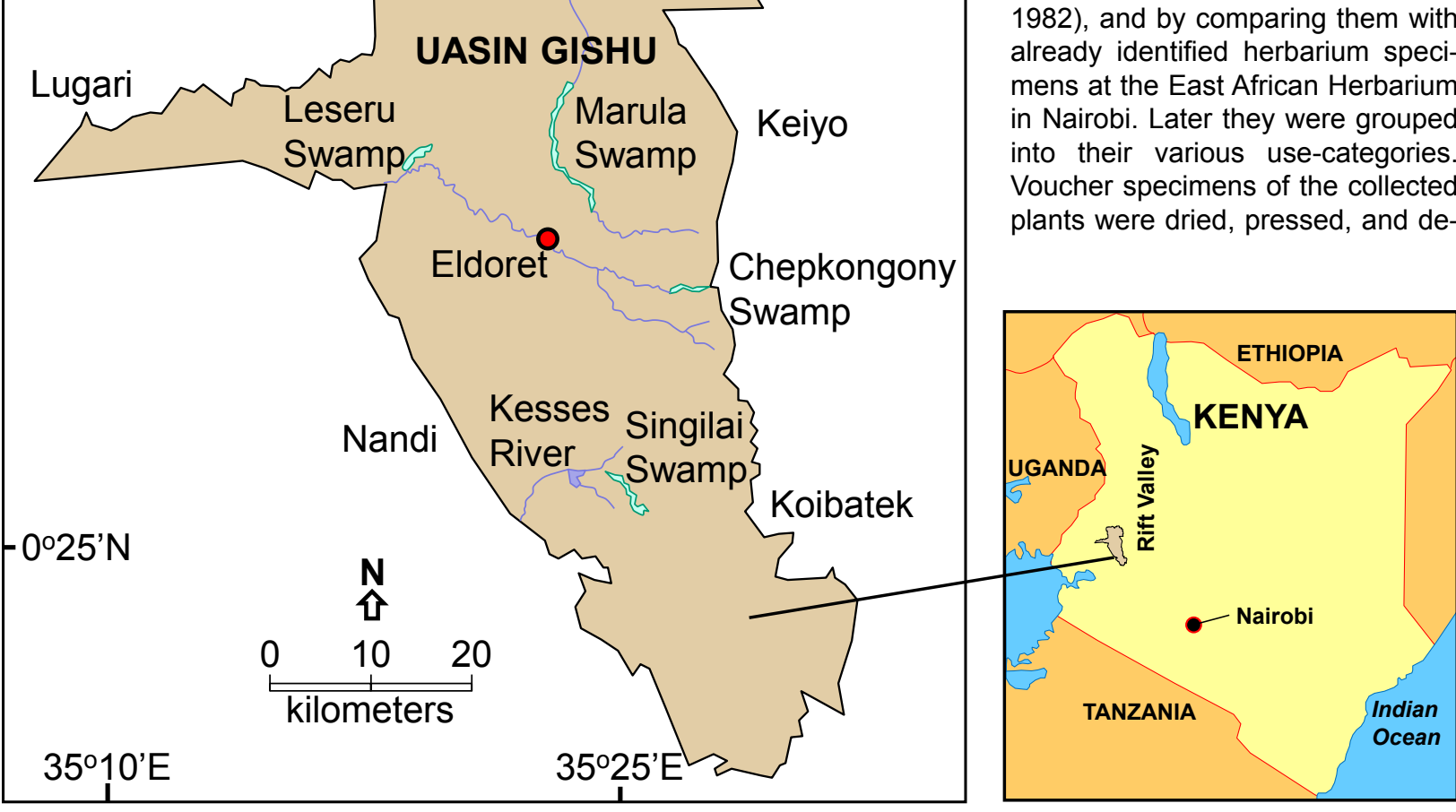

Figure 1. Uasin Gishu County, Kenya, with four study site swamps: Chepkongony, Leseru, Marula, and Singilai. 


\section{Mulei et al. - An Ethnobotanical Study of Swamp Wetland Vegetation in Uasin 317 Gishu County, Kenya}

posited in the herbarium of the Department of Biological Sciences, University of Eldoret.

Descriptive statistics were used to summarize the ethnobotanical data collected.

\section{Results}

The socio-demographic data characterizing the respondents interviewed in the four swamps is given in Table 1. From the 80 respondents, $68.7 \%$ were males and $31.3 \%$ females. Farmers dominated the respondents while artisans represented the smallest group. The largest respondent category was those above 35 years of age.

Fifty plant species distributed in 45 genera and 23 families and encompassing 4 different life forms were cited by the informants as having various traditional uses in the area (Table 2). The family Cyperaceae had the highest number of useful species followed by Fabaceae, Poaceae, Asteraceae, and Polygonaceae (Table 3). The most frequently used species were Pycreus nitidus (Lam.) J.Raynal, Cyperus papyrus L., and Typha latifolia L. (Table 4). Of the differ-
Table 1. Socio-demographic data of informants living near Chepkongony, Leseru, Marula, and Singilai swamps, Uasin Gishu County, Kenya.

\begin{tabular}{|c|c|c|}
\hline \multirow[t]{2}{*}{ Demographics } & \multicolumn{2}{|c|}{ Informants } \\
\hline & Number & Percent \\
\hline \multicolumn{3}{|l|}{ Gender } \\
\hline Male & 55 & 68.7 \\
\hline Female & 25 & 31.3 \\
\hline \multicolumn{3}{|l|}{ Age } \\
\hline Under 18 & 16 & 20.0 \\
\hline 19-35 years & 27 & 33.7 \\
\hline Above 35 years & 37 & 46.3 \\
\hline \multicolumn{3}{|l|}{ Occupation } \\
\hline Farmer & 51 & 63.8 \\
\hline Unemployed & 13 & 16.2 \\
\hline Casual laborer & 7 & 8.8 \\
\hline Student & 5 & 6.2 \\
\hline Artisan & 4 & 5.0 \\
\hline
\end{tabular}

Table 2. Useful plants reported for Chepkongony, Leseru, Marula, and Singilai swamps, Uasin Gishu County, Kenya. Habit: climber $(C)$, herb $(H)$, herb-grass $(G)$, shrub $(S)$, tree $(T)$. Plant part: bark $(B)$, fruit $(F)$, flowers $(F I)$, leaf $(L)$, pollen $(\mathrm{P})$, root $(\mathrm{R})$, stem $(\mathrm{S})$, whole plant $(\mathrm{W})$; mature $(\mathrm{m})$, young $(\mathrm{y})$. Languages: ${ }^{1}$ Keiyo, ${ }^{2}$ Kiswahili, ${ }^{3}$ Luhya, ${ }^{4} \mathrm{Nandi}$.

\begin{tabular}{|c|c|c|c|c|}
\hline Plants & Local Name & Habit & Part used & Uses \\
\hline \multicolumn{5}{|l|}{ Amaranthaceae } \\
\hline Amaranthus hybridus L. & Chepkerta $^{2}$ & $\mathrm{H}$ & $\mathrm{L}$ & Vegetable \\
\hline \multicolumn{5}{|l|}{ Apiaceae } \\
\hline Afroligusticum linderi (C.Norman) P.J.D.Winter & - & $\mathrm{H}$ & L, S & Fodder \\
\hline \multicolumn{5}{|l|}{ Apocynaceae } \\
\hline \multirow[t]{3}{*}{ Carissa spinarum L. } & \multirow[t]{3}{*}{ Legetetwa $^{2}$} & \multirow[t]{3}{*}{$S$} & L & Fodder \\
\hline & & & $\mathrm{F}$ & Edible, medicinal \\
\hline & & & $\mathrm{R}$ & Medicinal \\
\hline \multicolumn{5}{|l|}{ Asteraceae } \\
\hline \multirow[t]{2}{*}{ Acmella caulirhiza Delile } & \multirow[t]{2}{*}{ Putputiet $^{4}$} & \multirow[t]{2}{*}{$\mathrm{H}$} & $\mathrm{L}$ & Medicinal \\
\hline & & & $\mathrm{F}$ & Edible \\
\hline \multirow[t]{2}{*}{ Aspilia mossambicensis (Oliv.) Wild } & \multirow[t]{2}{*}{ Chepsitet $^{4}$} & $\mathrm{H}$ & $\mathrm{W}(\mathrm{y})$ & Fodder \\
\hline & & & $\mathrm{L}(\mathrm{m})$ & Dish-cleaning \\
\hline Baccharoides lasiopus (O.Hoffm.) H.Rob. & Yebengwet $^{2}$ & $S$ & $\mathrm{~L}$ & Fodder, medicinal \\
\hline Bidens pilosa $\mathrm{L}$. & Kipkoleitet $^{4}$ & $\mathrm{H}$ & $\mathrm{L}$ & Fodder, medicinal \\
\hline Galinsoga parviflora Cav. & Chepsitaki $^{1}$ & $\mathrm{H}$ & $L, S$ & Fodder \\
\hline \multicolumn{5}{|l|}{ Basellaceae } \\
\hline Basella alba L. & Nderema $^{2}$ & $\mathrm{C}$ & $\mathrm{L}$ & Vegetable \\
\hline \multicolumn{5}{|l|}{ Boraginaceae } \\
\hline Cynoglossum coeruleum A.DC. & Kimnambwet $^{4}$ & $\mathrm{H}$ & $\mathrm{L}$ & Medicinal \\
\hline
\end{tabular}




\begin{tabular}{|c|c|c|c|c|}
\hline Plants & Local Name & Habit & Part used & Uses \\
\hline \multicolumn{5}{|l|}{ Commelinaceae } \\
\hline Commelina diffusa Burm.f. & - & $\mathrm{H}$ & $\mathrm{W}$ & Fodder \\
\hline $\begin{array}{l}\text { Floscopa glomerata (Willd. ex Schult. \& Schult.f.) } \\
\text { Hassk. }\end{array}$ & - & $\mathrm{H}$ & W & Fodder \\
\hline \multicolumn{5}{|l|}{ Crassulaceae } \\
\hline Crassula granvikii Mildbr. & - & $\mathrm{H}$ & W & Fodder \\
\hline \multicolumn{5}{|l|}{ Cucurbitaceae } \\
\hline Zehneria scabra (L.f.) Sond. & Porowet $^{4}$ & C & $L, R$ & Medicinal \\
\hline \multicolumn{5}{|l|}{ Cyperaceae } \\
\hline Courtoisia sp. & Saoset $^{2}$ & $\mathrm{H}$ & W (y) & Fodder \\
\hline Cyperus ajax C.B.Clarke & Saoset $^{2}$ & $\mathrm{H}$ & L & Thatching \\
\hline \multirow[t]{2}{*}{ Cyperus digitatus Roxb. } & \multirow[t]{2}{*}{ Saoset $^{2}$} & \multirow[t]{2}{*}{$\mathrm{H}$} & $L(y)$ & Fodder \\
\hline & & & $\mathrm{L}(\mathrm{m})$ & Thatching \\
\hline \multirow[t]{3}{*}{ Cyperus papyrus L. } & \multirow{3}{*}{$\begin{array}{l}\text { Maruriat }{ }^{4} \\
\text { Matoko }^{3}\end{array}$} & \multirow[t]{3}{*}{$\mathrm{H}$} & $\mathrm{R}$ & Firewood \\
\hline & & & $S$ & $\begin{array}{l}\text { Firewood, fence, } \\
\text { mat-weaving, seats, } \\
\text { book covers, edible }\end{array}$ \\
\hline & & & $\mathrm{FI}$ & $\begin{array}{l}\text { Broom, green } \\
\text { manure, cultural }\end{array}$ \\
\hline Cyperus rotundus $\mathrm{L}$. & Saoset $^{2}$ & $\mathrm{H}$ & $\mathrm{L}$ & Fodder \\
\hline Pycreus nitidus (Lam.) J.Raynal & $\begin{array}{l}\text { Saoset }{ }^{4} \\
\text { Kumunyu }^{3}\end{array}$ & $\mathrm{H}$ & L & $\begin{array}{l}\text { Thatch, mulching, } \\
\text { brick cover, fodder } \\
\text { (young leaves), } \\
\text { medicinal, cultural, } \\
\text { provide shade } \\
\text { in fish ponds }\end{array}$ \\
\hline $\begin{array}{l}\text { Schoenoplectus corymbosus (Roth ex Roem. } \\
\text { \& Schult.) J.Raynal }\end{array}$ & - & $\mathrm{H}$ & $S$ & Fodder \\
\hline \multicolumn{5}{|l|}{ Fabaceae } \\
\hline \multirow[t]{2}{*}{ Acacia seye/ Delile } & \multirow[t]{2}{*}{ Chemnyaliliet $^{2}$} & \multirow[t]{2}{*}{$S$} & $\mathrm{~L}$ & Fodder \\
\hline & & & $S$ & Firewood, construction \\
\hline Aeschynomene abyssinica (A. Rich.) Vatke & $\begin{array}{l}\text { Koibeiyot }{ }^{4} \\
\text { Chepkopeyot }^{1}\end{array}$ & $S$ & $S$ & Construction, firewood \\
\hline Aeschynomene mimosifolia Vatke & Koibeiyot $^{2}$ & $S$ & L & Fodder \\
\hline Leucaena leucocephala (Lam.) de Wit & - & $T$ & $\mathrm{~S}$ & Construction, firewood \\
\hline $\begin{array}{l}\text { Senna didymobotrya (Fresen.) H.S.Irwin } \\
\text { \& Barneby }\end{array}$ & Senetwet ${ }^{1}$ & $\mathrm{~s}$ & L & Medicinal \\
\hline \multirow[t]{2}{*}{ Sesbania sesban (L.) Merr. } & \multirow[t]{2}{*}{ Koibeiyot $^{2}$} & \multirow[t]{2}{*}{$S$} & $S$ & $\begin{array}{l}\text { Construction, } \\
\text { fence, firewood }\end{array}$ \\
\hline & & & $\mathrm{R}$ & Medicinal \\
\hline \multicolumn{5}{|l|}{ Lamiaceae } \\
\hline Ajuga integrifolia Buch.-Ham. & Chelelgiat $^{4}$ & $\mathrm{H}$ & $\mathrm{L}$ & Medicinal \\
\hline Leonotis nepetifolia (L.) R.Br. & Chepchai $^{2}$ & $\mathrm{H}$ & L & Medicinal \\
\hline Ocimum kilimandscharicum Baker ex Gürke & - & $S$ & $L, R$ & Medicinal \\
\hline \multicolumn{5}{|l|}{ Lythraceae } \\
\hline Rotala tenella (Guill. \& Perr.) Hiern & - & $\mathrm{H}$ & W & Fodder \\
\hline
\end{tabular}


Mulei et al. - An Ethnobotanical Study of Swamp Wetland Vegetation in Uasin 319 Gishu County, Kenya

\begin{tabular}{|c|c|c|c|c|}
\hline Plants & Local Name & Habit & Part used & Uses \\
\hline \multicolumn{5}{|l|}{ Malvaceae } \\
\hline \multirow[t]{2}{*}{ Dombeya burgessiae Gerrard ex Harv. \& Sond. } & \multirow[t]{2}{*}{-} & \multirow[t]{2}{*}{$\mathrm{T}$} & $\mathrm{S}$ & Firewood, construction \\
\hline & & & $\mathrm{B}$ & String for construction \\
\hline \multirow[t]{3}{*}{ Pavonia urens Cav. } & \multirow{3}{*}{$\begin{array}{l}\text { Motoshe }^{2} \\
\text { Motosiet }^{2}\end{array}$} & \multirow[t]{3}{*}{$S$} & $S$ & Firewood \\
\hline & & & $\mathrm{B}$ & Rope \\
\hline & & & L & Dish-cleaning \\
\hline \multicolumn{5}{|l|}{ Myrtaceae } \\
\hline \multirow[t]{2}{*}{ Syzygium cordatum Hochst. ex Krauss } & \multirow[t]{2}{*}{-} & \multirow[t]{2}{*}{$T$} & $\mathrm{~F}$ & Edible \\
\hline & & & $\mathrm{S}$ & Firewood, construction \\
\hline \multicolumn{5}{|l|}{ Poaceae } \\
\hline Cynodon transvaalensis Burtt Davy & Susuat $^{2}$ & G & W & Fodder \\
\hline Digitaria scalarum (Schweinf.) Chiov. & Susuat $^{2}$ & G & $\mathrm{L}$ & Fodder \\
\hline Echinochloa pyramidalis (Lam.) Hitchc. \& Chase & Susuat $^{2}$ & $\mathrm{G}$ & $\mathrm{W}(\mathrm{y})$ & Fodder \\
\hline Leersia hexandra Sw. & Susuat $^{2}$ & $\mathrm{G}$ & $L, S$ & Fodder \\
\hline Panicum poioides Stapf. & Susuat $^{2}$ & $\mathrm{G}$ & L, S & Fodder \\
\hline $\begin{array}{l}\text { Pennisetum sphacelatum (Nees) T.Durand } \\
\text { \& Schinz }\end{array}$ & Seyiot $^{2}$ & G & $\mathrm{L}$ & Fodder \\
\hline \multicolumn{5}{|l|}{ Rosaceae } \\
\hline \multirow[t]{2}{*}{ Rubus apetalus Poir. } & \multirow[t]{2}{*}{ Monget $^{2}$} & \multirow[t]{2}{*}{$S$} & $\mathrm{~S}$ & Firewood \\
\hline & & & $\mathrm{F}$ & Edible \\
\hline \multicolumn{5}{|l|}{ Solanaceae } \\
\hline Solanum incanum L. & Lavutwi $^{4}$ & $S$ & $\mathrm{R}$ & Medicinal \\
\hline \multicolumn{5}{|l|}{ Phytolaccaceae } \\
\hline Phytolacca dodecandra L'Hér. & Kobot $^{2}$ & $S$ & $\mathrm{~S}$ & Firewood \\
\hline \multicolumn{5}{|l|}{ Polygonaceae } \\
\hline Persicaria decipiens (R.Br.) K.L.Wilson & Mutwet $^{4}$ & $\mathrm{H}$ & $\mathrm{L}, \mathrm{S}$ & Fodder \\
\hline Persicaria strigosa (R.Br.) Nakai & $\begin{array}{l}\text { Mutwet }^{4}, \\
\text { Cheborowa }^{2} \text {, } \\
\text { Loplopitiet }^{1}\end{array}$ & $\mathrm{H}$ & L, S & Fodder \\
\hline \multirow[t]{2}{*}{ Polygonum pulchrum Blume } & \multirow{2}{*}{$\begin{array}{l}\text { Mutwet }^{4}, \\
\text { Cheborowa }^{1}\end{array}$} & \multirow[t]{2}{*}{$\mathrm{H}$} & $\mathrm{L}$ & Fodder \\
\hline & & & $\mathrm{S}$ & Cultural, rope \\
\hline Rumex nepalensis Spreng. & Masisiriet $^{4}$ & $\mathrm{H}$ & $\mathrm{L}$ & Vegetable \\
\hline \multicolumn{5}{|l|}{ Typhaceae } \\
\hline \multirow[t]{4}{*}{ Typha latifolia L. } & \multirow[t]{4}{*}{ Cherugut $^{4}$} & \multirow[t]{4}{*}{$\mathrm{H}$} & $\mathrm{F}$ & Decoration \\
\hline & & & $P$ & Beauty powder \\
\hline & & & $L(m)$ & Thatch, cultural \\
\hline & & & $L(y)$ & Fodder \\
\hline \multicolumn{5}{|l|}{ Verbenaceae } \\
\hline Lantana camara L. & Lantana $^{4}$ & $S$ & $\mathrm{~S}$ & Firewood \\
\hline & & & $\mathrm{F}$ & Edible \\
\hline Vitaceae & & & & \\
\hline $\begin{array}{l}\text { Cyphostemma adenocaule (Steud. ex A. Rich.) } \\
\text { Desc. ex Wild \& R.B.Drumm. }\end{array}$ & Simet $^{2}$ & $\mathrm{C}$ & $L, R$ & Medicinal \\
\hline
\end{tabular}


Table 3. Plant families and numbers of species of useful plants reported for Chepkongony, Leseru, Marula, and Singilai swamps, Uasin Gishu County, Kenya.

\begin{tabular}{|l|c|}
\hline Family & Number of species \\
\hline Cyperaceae & 7 \\
\hline Fabaceae & 6 \\
\hline Poaceae & 6 \\
\hline Asteraceae & 5 \\
\hline Polygonaceae & 4 \\
\hline Lamiaceae & 3 \\
\hline Commelinaceae & 2 \\
\hline Malvaceae & 2 \\
\hline Amaranthaceae & 1 \\
\hline Apiaceae & 1 \\
\hline Apocynaceae & 1 \\
\hline Basellaceae & 1 \\
\hline Boranginaceae & 1 \\
\hline Crassulaceae & 1 \\
\hline Cucurbitaceae & 1 \\
\hline Lythraceae & 1 \\
\hline Myrtaceae & 1 \\
\hline Rosaceae & 1 \\
\hline Solanaceae & 1 \\
\hline Phytolaccaceae & 1 \\
\hline Typhaceae & 1 \\
\hline Verbanaceae & 1 \\
\hline Vitaceae & 1 \\
\hline
\end{tabular}

Table 4. Most frequently used (mentioned) plant species within Chepkongony, Leseru, Marula, and Singilai swamps, Uasin Gishu County, Kenya.

\begin{tabular}{|l|c|}
\hline Species & Frequency (\%) \\
\hline Pycreus nitidus (Lam.) J.Raynal & 62.5 \\
\hline Cyperus papyrus L. & 22.5 \\
\hline Typha latifolia L. & 21.1 \\
\hline Sesbania sesban (L.) Merr. & 16.3 \\
\hline $\begin{array}{l}\text { Aeschynomene abyssinica } \\
\text { (A.Rich.) Vatke }\end{array}$ & 15.0 \\
\hline Polygonum pulchrum Blume & 12.5 \\
\hline $\begin{array}{l}\text { Schoenoplectus corymbosus } \\
\text { (Roth ex Roem. \& Schult.) }\end{array}$ & 11.3 \\
\hline $\begin{array}{l}\text { Floscopa glomerata (Willd. ex } \\
\text { Schult. \& Schult.f.) Hassk. }\end{array}$ & 7.5 \\
\hline Acacia seyal Delile & 7.5 \\
\hline Leersia hexandra Sw. & 6.3 \\
\hline Basella alba L. & 6.3 \\
\hline
\end{tabular}

ent growth forms of plants collected, herbs comprised the highest proportion followed by shrubs, trees, and climbers (Figure 2). The plants collected were differentiated into 21 use categories (Figure 3). Those used as fodder comprised the biggest proportion followed by, those used as medicine, firewood, construction, and food in that order.

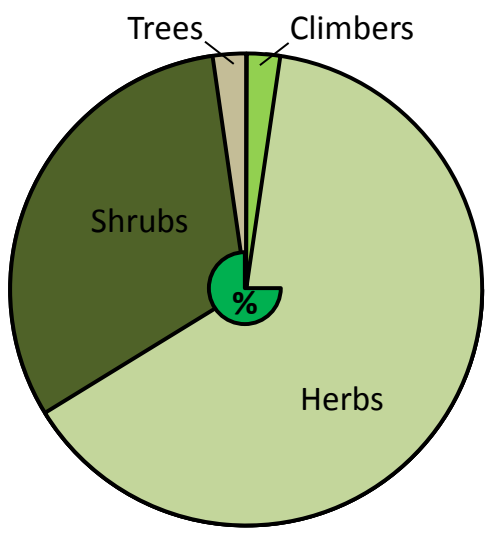

Figure 2. Growth forms of the useful plants reported in Chepkongony, Leseru, Marula, and Singilai swamps, Uasin Gishu County, Kenya.

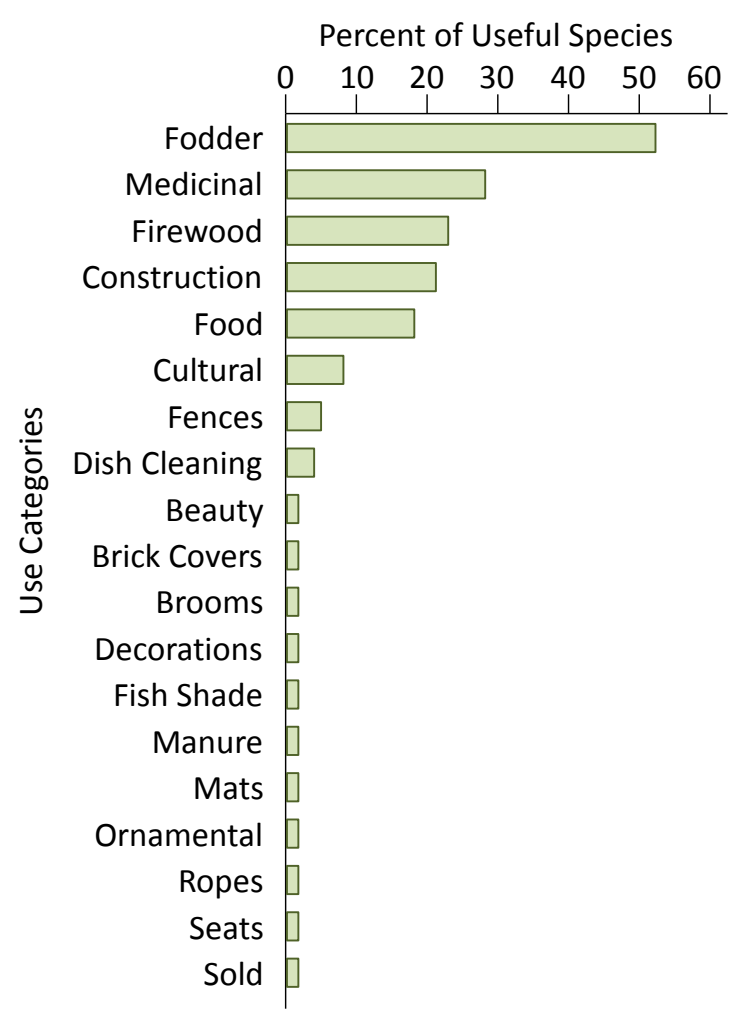

Figure 3. Reported frequency of plant use categories in Chepkongony, Leseru, Marula, and Singilai swamps, Uasin Gishu County, Kenya. 


\section{Mulei et al. - An Ethnobotanical Study of Swamp Wetland Vegetation in Uasin 321 Gishu County, Kenya}

Different parts of the plants collected were used for various purposes (Table 5). A very high proportion of interviewees $(89 \%)$ indicated that they used plant leaves as fodder, while $33 \%$ of respondents used stems as firewood. Plants that were used for medicinal purposes were useful in treating a total of 19 ailments, and some con-

ditions-e.g., mouth ulcers, malaria, stomach ache, dysentery, and infertility in women-were treated using more than one species (Table 6). Of the plants used as medicines, about half were prepared for use by boiling to make decoctions (Table 7).

Table 5. Frequency of use (\%) of various plant parts by people living near Chepkongony, Leseru, Marula, and Singilai swamps, Uasin Gishu County, Kenya. Frequencies are the percent of respondents who use a particular part for a particular use category and are not cummulative across categories or plant parts.

\begin{tabular}{|c|c|c|c|c|c|c|}
\hline \multirow{2}{*}{$\begin{array}{l}\text { Use } \\
\text { categories }\end{array}$} & \multicolumn{6}{|c|}{ Plant part use respondent frequency (\%) } \\
\hline & Stem & Roots & Leaves & Bark & Fruits & Flowers \\
\hline Food & - & - & 21.3 & - & 16.0 & - \\
\hline Building & 21.3 & - & - & 1.3 & - & - \\
\hline Fodder & 7.5 & - & 88.8 & - & - & 2.5 \\
\hline Medicinal & 1.3 & 11.3 & 16.3 & - & - & 2.5 \\
\hline Cultural usage & 3.8 & - & 27.5 & - & - & 1.3 \\
\hline Firewood & 32.5 & 7.5 & - & - & - & - \\
\hline Mat use & 17.5 & - & - & - & - & - \\
\hline Fence & 20.0 & - & - & - & - & - \\
\hline Thatching & - & - & 61.3 & - & - & - \\
\hline Rope-making & - & - & - & 2.5 & - & - \\
\hline Dish-cleaning & - & - & 5.0 & - & - & - \\
\hline Seat-making & 3.8 & - & - & - & - & - \\
\hline Brick-covering & 7.5 & - & - & - & - & - \\
\hline Mulching & - & - & 2.5 & - & - & - \\
\hline Green manure & - & - & - & - & - & 1.3 \\
\hline
\end{tabular}

Table 6. Number of species used to treat different medical conditions as reported by users of Chepkongony, Leseru, Marula, and Singilai swamps, Uasin Gishu County, Kenya.

\begin{tabular}{|c|c|c|c|}
\hline Medical conditions & $\begin{array}{c}\text { Number of } \\
\text { species }\end{array}$ & Medical conditions & $\begin{array}{c}\text { Number of } \\
\text { species }\end{array}$ \\
\hline Dysentery/diarrhea & 2 & Impotence & 1 \\
\hline Infertility in women & 2 & Pain & 1 \\
\hline Malaria in man and animals & 2 & Rheumatism & 1 \\
\hline Mouth ulcers & 2 & Ringworms & 1 \\
\hline Stomachache & 2 & Skin rash & 1 \\
\hline Burn wounds & 1 & Stomach problems after delivery & 1 \\
\hline Chest problems & 1 & Thrush & 1 \\
\hline Colds & 1 & Thyroid/goiter & 1 \\
\hline Digestion problems & 1 & Wounds & 1 \\
\hline
\end{tabular}

Earache

Table 7. Methods used to prepare medicinal plants as reported by users of Chepkongony, Leseru, Marula, and Singilai swamps, Uasin Gishu County, Kenya.

\begin{tabular}{|l|l|l|l|l|}
\hline Method used & Species \\
\hline Boiling & 9 & Method used & Species \\
\hline Grinding & 5 & Burning \& boiling & 1 \\
\hline Burning \& grinding & 2 & Chewing & 1 \\
\hline Crushing \& homogenizing in water & 1 \\
\hline
\end{tabular}




\section{Discussion}

The prevalence of farmers among the respondents interviewed in this study can be explained by the fact that Uasin Gishu County is predominantly an agricultural area where a majority of the residents of the local communities engage in farming activities. Although male respondents were the majority of those interviewed, this does not in any way imply that men had more information on the traditional uses of plants than women. The low number of female respondents could be attributed to the fact that women who were approached, in many instances, shied away from the interviews.

In many parts of Kenya, wetland plants have been traditionally used, though at a very small scale and mainly for making mats, baskets, ropes, roofing material, and firewood (Gichuki et al. 2001). However, this has changed following the emergence of commercial exploitation of wetland plants (Abila 2002, Otieno et al. 1998). In this study, 50 species were documented as being useful in various ways to the communities living adjacent to the swamps. This suggests that despite the wetland-adjacent communities being exposed to influences from modern culture, they still preserved their knowledge of the uses of many of the plants occurring around them. Most of the plants exploited by the swamp-adjacent communities were herbs, a fact that can be explained by the abundance and yearround availability of herbaceous species in the study area. Grazing of animals in wetlands seems to be the most widespread use of wetlands in Uasin Gishu County. The likely reason for this is that wetland vegetation provides the most reliable source of fodder for animals during the dry season. A similar observation was made by Abila et al. (2005) in a study of wetlands located around Lake Victoria.

The use of several plant species as firewood and food by people in the study area suggests that the communities living around the swamps still depend on the natural environment for their energy and food needs. Some of the plants reported here as being used as sources of foode.g., Basella alba L., Lantana camara L., Amaranthus hybridus L., and Rubus apetalus Poir.-also have similar uses in other parts of Kenya (Mathenge 1997, Maundu 1997).

The species that was most frequently mentioned by the respondents interviewed in this study was $P$. nitidus. This species is widely used as fodder and thatching material by the wetland-adjacent communities, and it is abundant in all the swamps. A previous study by Odongo (1996) also revealed that this species, together with Pennisetum spp., were used as thatching material by communities living around the swamps in Uasin Gishu County. The high cost of purchasing alternative roofing materials like iron sheets, nails, and timber could be the reason why the communities living around the four swamps have resorted to the use of cheaper, locally-sourced roofing materials.

The frequency of use of $C$. papyrus was second to that of $P$. nitidus. However, $C$. papyrus only occurs in Marula swamp, and it is used for many purposes (fencing, firewood, furniture making, book covers, fodder, construction, mat weaving, etc.). The fact that it has many uses could explain its high frequency of mention. This species has been documented in other swamps around the country as being useful for making mats, baskets, and furniture (Abila et al. 2005, Terer et al. 2012). Its use for craft production has also been reported around the wetlands in Kwa Zulu Natal in South Africa (Kotze \& Traynor 2011). Mats and baskets are popular as they are utility products and need continual replacement in households. Papyrus also has the potential for use as paper and fodder (Muthuri \& Kinyamario 1989) and provision of energy (Jones 1984). The frequency of usage of other species was relatively low because, comparatively, they had fewer uses and/or they occurred in just a few swamps.

Medicinal plants documented in this study were used for the treatment of 19 ailments. The most commonly reported medical conditions were malaria, stomach ache, ringworm, dysentery, and thrush. The presence of medicinal plants and associated ethnomedicinal knowledge indicates that the swamps likely have useful pharmacochemical diversity. This knowledge correlates with uses reported elsewhere. For example, the leaves of Ajuga integrifolia Buch.-Ham. and Senna didymobotrya (Fresen.) H.S.Irwin \& Barneby were used for the treatment of malaria while those of Ocimum kilimandscharicum Baker ex Gürke and Zehneria scabra (L.f.) Sond. were used to treat stomach ache. Ajuga integrifolia has been used for malaria treatment in Kenya (Cocquyt et al. 2011, Gitua et al. 2012, Kuria et al. 2002) while the leaves of Z. scabra have elsewhere been found to be useful for treating skin diseases, gonorrhoea, syphilis, and malaria (Moshi et al. 2012).

These results also show that there were species which had multiple uses. For example C. papyrus was used as firewood, in building, weaving mats, fencing, and fodder, and Acacia seyal Delile was used as fodder, in building, and firewood. This mirrors the work of Saharia and Sarma (2011) which found similar indigenous uses of wetland plants in India.

\section{Conclusion}

This study illustrates the usage of wetland plants by communities living around the four swamps in Uasin Gishu County. This knowledge is still part of the cultural heritage in these communities. The plants are used for various purposes such as fodder, medicines, firewood, for building, and food. Those that are medicinal are used to treat a spectrum of human ailments such as malaria, mouth ul- 


\section{Mulei et al. - An Ethnobotanical Study of Swamp Wetland Vegetation in Uasin 323 Gishu County, Kenya}

cers, stomach ache, dysentery, skin rash, and infertility. Preservation of this knowledge is important for posterity.

\section{Acknowledgments}

The authors are grateful to Moi University for financial assistance through the Committee of Dean's Fund and Moi University Research Fund to JMM. We also thank the local informants who shared their knowledge on the use of wild plants. We acknowledge and thank Bernard Wanjohi of University of Eldoret (formerly Chepkoilel University College) and David Okebiro, formerly of the East African Herbarium, for their assistance in plant identification. The assistance given by Hellen Ruto and Joel Kemboi, both of University of Eldoret, during field work is also gratefully acknowledged.

\section{Literature Cited}

Abila, R. 2002. Utilisation and economic valuation of the Yala Swamp wetland. Pp. 89-95 in Strategies for Wise Use of Wetlands: Best practices in participatory management. Proceedings of 2nd International Conference on Wetlands and Development, Dakar, Senegal, 8-14 November 1998. Edited by M. Gawler. Wetlands International IUCN, WWF Publication No. 56, Wageningen, The Netherlands.

Abila, R., J.O. Rasowo \& J. Manyala. 2005. Biodiversity and sustainable management of a tropical wetland lake ecosystem: A case study of Lake Kanyaboli, Kenya. Pp. 205-209 in Proceedings of the 11th World Lakes Conference. Nairobi, Kenya, 31 October to 4 November 2005. Volume 2. Edited by E.O. Odada, D.O. Olago, W. Ochola, M. Ntiba, S. Wandiga, N. Gichuki \& H. Oyieke. International Lake Environment Committee, Japan; Pan African START Secretariat, Nairobi, Kenya; and Ministry of Water and Irrigation, Kenya.

Agnew, A.D.Q. \& S. Agnew. 1994. Upland Kenya Wild Flowers. A flora of the ferns and herbaceous flowering plants of upland Kenya. Second Edition. East African Natural History Society, Nairobi, Kenya.

Bayafers, T. 2000. A Floristic Analysis and Ethnobotanical Study of the Semi-Wetland of Cheffa Area, South Welo, Ethiopia. M.Sc. Thesis, Addis Ababa University, Ethiopia.

Beentje, H.J. 1994. Kenya Trees, Shrubs and Lianas. National Museum of Kenya, Nairobi, Kenya.

Benz, B.F., J. Cevallos E., F. Santana M., J. Rosales A. \& S. Graf M. 2000. Losing knowledge about plant use in the Sierra de Manantlan Biosphere Reserve, Mexico. Economic Botany 54:183-191.
Chapman, L.J., J. Balirwa, F.W.B. Bungenyi, C. Chapman \& T.L. Crisman. 2001. Wetlands of East Africa: Biodiversity, exploitation, and policy perspectives. Pp. 101-131 in Biodiversity in Wetlands: Assessment, function and conservation. Volume 2. Edited by B. Gopal, W.J. Junk \& J.A. Davis. Backhuys Publishers, Leiden, The Netherlands.

Clayton, W.D. 1970. Gramineae Part I. Flora of Tropical East Africa. Crown Agents for Overseas Governments and Administration, London, U.K.

Clayton, W.D. 1974. Gramineae Part II. Flora of Tropical East Africa. Crown Agents for Overseas Governments and Administration, London, U.K.

Clayton, W.D. 1982. Gramineae Part III. Flora of Tropical East Africa. Crown Agents for Overseas Governments and Administration, London, U.K.

Cocquyt, K., P. Cos, P. Herdewijn, L. Maes, P.E. Van den Steen \& G. Laekeman. 2011. Ajuga remota Benth.: From ethnopharmacology to phytomedical perspective in the treatment of malaria. Phytomedicine 18(14):1229-1237.

Gichuki, N.N., H.A. Oyieke \& G.G. Ndiritu. 2001. Assessment and monitoring of wetlands for conservation and development in dry lands: A case study of Kajiado County, Kenya. Pp. 8-14 in Wetland Inventory, Assessment and Monitoring: Practical techniques and identification of major issues. Proceedings of Workshop 4, 2nd International Conference on Wetlands and Development, Dakar, Senegal, November 1998. Edited by C.M. Finlayson, N.C. Davidson \& N.J Stevenson. Supervising Scientist Report 161, Supervising Scientist, Darwin, Northern Territory, Australia.

Gitua, J.N., D.R. Muchiri \& X.A. Nguyen. 2012. In vivo antimalarial activity of Ajuga remota water extracts against Plasmodium berghei in mice. Southeast Asian Journal of Tropical Medicine and Public Health 43(3):545-548.

GoK. 2002. Final Draft Sessional Paper on National Wetlands Conservation Management. Government of Kenya, Nairobi, Kenya.

Haines, R.W. \& K.A. Lye. 1983. The Sedges and Rushes of East Africa. East African Natural History Society, Nairobi, Kenya.

Ibrahim, M.K. \& C.H.S. Kabuye. 1987. An Illustrated Manual of Kenya Grasses. Food and Agriculture Organization of the United Nations, Rome, Italy.

Jones, M.B. 1984. Biofuel development in Central Africa: Technology transfer from Ireland. Pp. 355-361 in Energy for Rural and Island Communities III. Proceedings of the Third International Conference held at Inverness, Scot- 
land, September 1983. Edited by J. Twidell, F. Riddoch \& B. Grainger. Pergamon, Oxford, U.K.

Kahuthu, R., T. Muchoki \& C. Nyaga. 2005. Kilifi District Strategic Plan 2005-2010 for Implementation of the National Population Policy for Sustainable Development. National Coordination Agency for Population and Development, Nairobi, Kenya.

Khan, S.W. \& S. Khatoon. 2007. Ethnobotanical studies on useful trees and shrubs of Haramosh and Bugrote Valleys, in Gilgit northern areas of Pakistan. Pakistan Journal of Botany 39:699-710.

Kotze, D.C. \& C.H. Traynor. 2011. Wetland plant species used for craft production in KwaZulu-Natal, South Africa: Ethnobotanical knowledge and environmental sustainability. Economic Botany 65:271-282.

Kuria, K.A., H. Chepkwony, C. Govaerts, E. Roets, R. Busson, P. De Witte, I. Zupko, G. Hoornaert, L. Quirynen, L. Maes, L. Janssens, J. Hoogmartens \& G. Laekeman. 2002. The antiplasmodial activity of isolates from Ajuga remota. Journal of Natural Products 65(5):789-793.

Lulekal, E., E. Kelbessa, T. Bekele \& H. Yineger. 2008. An ethnobotanical study of medicinal plants in Mana Angetu County, southeastern Ethiopia. Journal of Ethnobotany and Ethnomedicine 4:10.

Mathenge, L. 1997. Nutrition value and utilization of indigenous vegetables in Kenya. Pp. 76-77 in Proceedings of the IPGRI International Workshop on Genetic Resources of Traditional Vegetables in Africa: Conservation and use. 29-31 August 1995, ICRAF- HQ Nairobi, Kenya. Edited by L. Guarino. International Plant Genetic Resource Institute, Rome, Italy.

Maundu, P.M. 1997. The status of traditional vegetable utilization in Kenya. Pp. 66-75 in Proceedings of the IP. GRI International Workshop on Genetic Resources of Traditional Vegetables in Africa: Conservation and use. 2931 August 1995, ICRAF- HQ Nairobi, Kenya. Edited by L. Guarino. International Plant Genetic Resource Institute, Rome, Italy.

Moshi, M.J., D.F. Otieno \& A. Weisheit. 2012. Ethnomedicine of the Kagera region, north western Tanzania. Part 3: Plants used in traditional medicine in Kikuku village, Muleba District. Journal of Ethnobiology and Ethnomedicine 8:14.
Muthuri, F.M. \& J.I. Kinyamario. 1989. Nutritive value of papyrus (Cyperus papyrus, Cyperaceae), a tropical emergent macrophyte. Economic Botany 43:23-30.

Njuguna, P.K. 1996. Building an Inventory of Kenya's Wetlands: A biological inventory of wetlands of Uasin Gishu County of Kenya. Kenyan Wetlands Working Group, Nairobi, Kenya.

Odongo, O.R. 1996. Building an Inventory of Kenya's Wetlands: An ethnobotany study of wetland plants of Uasin Gishu County of Kenya. Kenyan Wetlands Working Group, Nairobi, Kenya.

Otieno, M., S. Imende, G. Haya, S. Kibos \& Z. Ouma. 1998. Sustainable Utilization and Management of Wetlands and Wetlands Products Pilot Project: Market survey of wetlands products in Busia, Siaya, Kisumu and Kisii counties report. Lake Victoria Environmental Management Project, Entebbe, Uganda.

Peters, C.M. 1996. Beyond nomenclature and use: A review of ecological methods for ethnobotanists. Pp. 241273 in Selected Guidelines for Ethnobotanical Research: A field manual. Edited by M.N. Alexiades \& J.W. Sheldon. The New York Botanical Garden, Bronx, New York, U.S.A.

Saharia, S. \& C.M. Sarma. 2011. Ethno-medicinal studies on indigenous wetland plants in the tea garden tribes of Darrang and Udalguri district, Assam, India. NeBIO 2:2733.

Signorini, M.A., M. Piredda \& P. Bruschi. 2009. Plants and traditional knowledge: An ethnobotanical investigation on Monte Ortobene (Nuoro, Sardinia). Journal of Ethnobiology and Ethnomedicine 5:6.

Terer, T., A.M. Muasya, F. Dahdouh-Guebas, G.G. Ndiritu \& L. Triest. 2012. Integrating local ecological knowledge and management practices of an isolated semi-arid papyrus swamp (Loboi, Kenya) into a wider conservation framework. Journal of Environmental Management 93:71-84.

Zent, S. 1999. The quandary of conserving ethnoecological knowledge. A Piaroa example. Pp. 90-124 in Ethnoecology: Knowledge, resources and rights. Edited by T.L. Gragson \& B. Blount. The University of Georgia Press, Athens, Georgia, U.S.A. 